\title{
Strafrecht
}

\section{Het Europees Openbaar Ministerie komt eraan: waakhond of papieren tijger?}

\author{
Mr. Y. de Vries en mr. S.J. Lopik*
}

Op 1 augustus 2018 heeft de Europese Commissie (hierna: Commissie) bevestigd dat Nederland gaat deelnemen aan het Europees Openbaar Ministerie (hierna: $\mathrm{EOM}) .{ }^{1}$ Het EOM is een onafhankelijk vervolgingsorgaan dat, in het kort, bevoegd is om strafbare feiten die ten koste gaan van de EU-begroting te onderzoeken, vervolgen en voor de nationale strafrechter te brengen, een taak die tot dusver was voorbehouden aan de nationale vervolgingsautoriteiten (in Nederland het Openbaar Ministerie). Dit past in een trend waarbij de Unie, die historisch gezien indirect handhaaft, steeds vaker aan directe handhaving doet. ${ }^{2}$ Ook past het bij een Unie die steeds meer strafrechtelijke taken naar zich toetrekt: waar strafrechtelijke samenwerking tot het Verdrag van Lissabon nog behoorde tot de derde pijler, bestaan inmiddels meerdere Europeesrechtelijke strafrechtelijke agentschappen, waaronder Eurojust, Europol en OLAF. Er wordt ook wel gesproken van een europeanisering van het Nederlands strafrecht. ${ }^{3}$ De ambities van de Commissie voor het EOM strekken echter verder dan alleen het bestrijden van fraude. In deze bijdrage gaan wij in op de achtergrond van het EOM, de inrichting en taken van het EOM en de betekenis daarvan voor personen en ondernemingen die verdacht worden van strafbare feiten die binnen de bevoegdheid van het EOM vallen.

Verordening (EU) 2017/1939 van de Raad van 12 oktober 2017 betreffende naumere samenwerking bij de instelling van het Europees Openbaar Ministerie('EOM'), PbEU 2017, L 283/1-71.

* Mr. Y. (Yvo) de Vries is advocaat bij Allen \& Overy te Amsterdam. Mr. S.J. (Sjoerd) Lopik is advocaat bij Allen \& Overy te Amsterdam.

1. Besluit (EU) $2018 / 1094$ van de Commissie van 1 augustus 2018 ter bevestiging van de deelname van Nederland aan de nauwere samenwerking bij de instelling van het Europees Openbaar Ministerie, PbEU 2018, L 196/1.

2. Zie voor een overzicht K.H.P. Bovend'Eert, 'Fundamentele rechten in het gedrang bij directe handhaving door EU-handhavingsautoriteiten', Strafblad 2017/6.

3. M.J.J.P. Luchtman en R.J.G.M. Widdershoven, 'Het Nederlands strafrecht in de ban van het Unierecht', Ars Aequi 2018, p. 873-889.

\begin{abstract}
Richtlijn (EU) 2017/1371 van het Europees Parlement en de Raad van 5 juli 2017 betreffende de strafrechtelijke bestrijding van fraude die de financiële belangen van de Unie schaadt, PbEU 2017, L 198/29-41.
\end{abstract}

\section{Inleiding}

Fraude die ten koste gaat van EU-middelen is een omvangrijk probleem. In 2017 werden bij de Commissie 1146 frauduleuze onregelmatigheden gemeld, waarmee in totaal circa 467 miljoen euro was gemoeid. ${ }^{4}$ Daarom voert de Commissie al jaren een actief antifraudebeleid. Daarnaast doet het Europees bureau voor fraudebestrijding (hierna: OLAF) onderzoek naar fraudegevallen waardoor de financiële belangen van de EU worden geschaad. De Commissie, noch OLAF is echter bevoegd om een zaak voor een strafrechter te brengen. Daarvoor zijn zij afhankelijk van de medewerking van en samenwerking tussen de lidstaten. Dit is van oudsher een knelpunt en een doorn in het oog voor de Commissie. ${ }^{5}$ Volgens de Commissie reageren de justitiële autoriteiten van de lidstaten vaak te traag, ligt het vervolgingspercentage te laag ${ }^{6}$ en zijn de verschillen tussen de lidstaten te groot. Daarmee zouden de lidstaten tekort schieten in hun verplichting, op grond van artikel 325 VWEU, om doeltreffende, gelijkwaardige en afschrikkende maatre-

4. Report from the Commission to the European Parliament and the Council: 29th Annual Report on the Protection of the European Union's financial interests - Fight against fraud - 2017, COM(2018)533 final, p. 15.

5. Zie bijvoorbeeld Speciaal verslag nr. 8/98 van de Rekenkamer over de diensten van de Commissie die specifiek zijn betrokken bij de fraudebestrijding, met name de 'Unité de coordination de la lutte antifraude' (UCLAF), vergezeld met antwoorden van de Commissie, PbEU 1998, C 230/1, punt 3.19-3.27.

6. De helft van de volbrachte onderzoeken van OLAF leidt tot een sepot van de nationale vervolgingsautoriteiten, zie M. Rabaey, 'Europese fraude blijft dikwijls onbestraft: Meer dan de helft van onderzoeken wordt door justitie uit lidstaten geseponeerd', De Morgen 6 februari 2017, www.demorgen.be/buitenland/europese-fraude-blijft-dikwijlsonbestraft-bc8370dd 
gelen te nemen om fraude die de financiële belangen van de Unie schaadt te bestrijden. Verder meent de Commissie dat grensoverschrijdende coördinatie en informatie-uitwisseling, ondanks de inspanningen van de bestaande organen zoals Europol, Eurojust en OLAF, onvoldoende is omdat deze worden beperkt doordat de bevoegdheden zijn verdeeld over verschillende instanties in verschillende lidstaten. ${ }^{7}$ Met andere woorden, de nationale vervolgingsautoriteiten werken niet goed samen. De oplossing: het EOM. Het is de bedoeling dat het EOM eind 2020 aan de slag gaat. ${ }^{8}$

In dit artikel geven wij ten eerste een achtergrond van het EOM. Wij bespreken daarbij de taken en de inrichting van het EOM, alsook de procedure van een EOMonderzoek. Vervolgens bespreken wij de rol die het EOM zal innemen ten opzichte van OLAF. Daarna kunnen wij concluderen wat de komst voor het EOM zal betekenen voor het rechtssubject. Zijn de rechten van de verdachte voldoende gewaarborgd tijdens een strafrechtelijke vervolging door het EOM?

\section{Achtergrond van het EOM}

De idee van een EOM is niet nieuw. ${ }^{9}$ In de jaren negentig hebben de Commissie en het Europees Parlement een wetenschappelijk onderzoek doen verrichten naar de mogelijkheden om fraudebestrijding te verbeteren. Twee belangrijke voorstellen die uit dat onderzoek naar voren kwamen, waren een verdergaande harmonisatie van materieel en formeel strafrecht en handhaving door een gecentraliseerde eenheid (zoals het EOM) ${ }^{10}$ Beide voorstellen zijn door de Commissie opgepakt. In het kader van de totstandkoming van het Verdrag van Nice heeft de Commissie tevergeefs de invoering van een EOM geopperd. ${ }^{11}$ Dat voorstel werd opgevolgd door een Groenboek over een EOM. ${ }^{12}$ Met het Verdrag van Lissabon kreeg de Commissie wat zij nodig had om dit idee te realiseren: een duidelijke rechtsgrondslag. Artikel 86 VWEU voorziet namelijk expliciet in de mogelijkheid om bij verordening een EOM in te stellen. $\mathrm{Na}$ eerst uitvoerig het draagvlak onder lidstaten te hebben onderzocht, heeft de Commissie in 2013 een

7. Voorstel voor een verordening van de Raad tot instelling van het Europees Openbaar Ministerie, $\operatorname{COM(2013)} 534$ final, p. 2; zie over het voorstel W. Geelhoed, 'Het Europees Openbaar Ministerie tussen soevereiniteit en effectiviteit', NtEr 2014/2-3, p. 75.

8. Zie bijvoorbeeld 'European Public Prosecutor's Office', www.consilium. europa.eu/en/policies/eppo.

9. Zie nader W. Geelhoed, 'Eurojust en het Europees Openbaar Ministerie', Strafblad 2008/66, p. 598

10. M. Delmas-Marty en J.A.E. Vervaele (red.), The Implementation of the Corpus Juris in the Member States. Penal provisions for the protection of European Finances, Antwerpen: Intersentia 2001, p. 12-43.

11. Additional Commission contribution to the Intergovernmental Conference on institutional reforms of 29 September 2000: the criminal protection of the Community's financial interests: a European Prosecutor, $\operatorname{COM}(2000) 608$.

12. Groenboek inzake de strafrechtelijke bescherming van de financiële belangen van de Gemeenschap en de instelling van een Europese officier van justitie van 11 december 2001, COM(2001) 715 def. en het vervolgverslag van 19 maart 2003, $\operatorname{COM(2003)} 128$ def. voorstel voor een verordening tot instelling van het EOM ingediend. ${ }^{13}$ Het wetgevingsproces verliep niet zonder slag of stoot. Veertien nationale parlementen hebben zorgen geuit over het voorstel en elf daarvan, waaronder de Nederlandse Eerste Kamer ${ }^{14}$ en Tweede Kamer, ${ }^{15}$ verwierpen het voorstel met een zogenoemde 'gele kaart'. Hun zorgen hielden voornamelijk verband met subsidiariteit en het risico van uitholling van OLAF en Eurojust. ${ }^{16}$ De Commissie heeft in een mededeling op die zorgen gereageerd. De strekking daarvan was dat het voorstel strookte met het subsidiariteitsbeginsel van artikel 5 lid 3 VEU en daarom niet ingetrokken of gewijzigd hoefde te worden. ${ }^{17}$

De verordening is met enkele wijzigingen, die zover relevant hierna nog aan de orde komen, vastgesteld op 15 oktober 2017 (hierna: EOM-verordening). Daarnaast heeft de Commissie een voorstel gedaan voor een richtlijn die minimumregels vaststelt voor het omschrijven van strafbare feiten en sancties betreffende de bestrijding van fraude en andere onwettige activiteiten waardoor de financiële belangen van de Unie worden geschaad. Deze richtlijn (hierna: Richtlijn (EU) 2017/1371) is op 5 juli 2017 vastgesteld. ${ }^{18}$ Een belangrijk element van Richtlijn (EU) 2017/1371 is dat deze een definitie geeft van fraude waardoor de financiële belangen van de Unie worden geschaad. ${ }^{19}$ Deze definitie is, in de EOM-verordening, bepalend voor de bevoegdheidsverdeling tussen het EOM en de nationale vervolgingsautoriteiten.

\section{Taak van het EOM}

Het EOM is een onafhankelijk en gedecentraliseerd vervolgingsorgaan van de EU dat rechtspersoonlijkheid bezit. ${ }^{20}$ Onafhankelijk betekent, in dit verband, dat de aanklagers en personeelsleden van het EOM in het belang van de gehele Unie handelen en geen instructies mogen vragen of aanvaarden van derden, waaronder ook lidstaten, instellingen en organen van de EU. Het EOM moet wel in zijn jaarverslagen verantwoording afleggen

13. Voorstel voor een verordening van de Raad tot instelling van het Europees Openbaar Ministerie van 17 juli 2013, COM(2013) 534 final.

14. Kamerstukken / 2013/14, 33709, C.

15. Kamerstukken I/ 2013/14, 33709, 2.

16. Zie bijvoorbeeld Position Paper Tweede Kamer inzake oprichting van een Europees Openbaar Ministerie (EOM), Den Haag, 11 april 2014. Voor een overzicht van de bezwaren tegen het EOM, zie J.A.E. Vervaele, 'The European Public Prosecutor's Office (EPPO): Introductory Remarks', in: W. Geelhoed, L.H. Erkelens en A.W.H. Meij (red.), Shifting Perspectives on the European Public Prosecutor's Office, The Hague: T.M.C. Asser Press 2018, p. 11-14.

17. Mededeling van de Commissie aan het Europees Parlement, de Raad en de Nationale Parlementen over de heroverweging van het voorstel voor een verordening van de Raad tot instelling van het Europees Openbaar Ministerie wat betreft het subsidiariteitsbeginsel, overeenkomstig protocol 2, $\operatorname{COM(2013)~} 851$ final.

18. Richtlijn (EU) 2017/1371 van het Europees Parlement en de Raad van 5 juli 2017 betreffende de strafrechtelijke bestrijding van fraude die de financiële belangen van de Unie schaadt, PbEU 2017, L 198/29.

19. Art. 3 Richtlijn (EU) $2017 / 1371$.

20. Art. $3 \mathrm{EOM}$-verordening. 
over zijn algemene beleid aan het Europees Parlement, de Commissie en de Raad. ${ }^{21}$ Het EOM is belast met het instellen van onderzoek naar en het vervolgen en voor de rechter brengen van daders van strafbare feiten die de financiële belangen van de Unie, zoals bedoeld in Richtlijn (EU) 2017/1371, schaden. ${ }^{22}$ De financiële belangen van de Unie omvatten alle ontvangsten, uitgaven en activa die worden gedekt door, zijn verworven in het kader van, of zijn verschuldigd aan (1) de begroting van de Unie en (2) kortweg, de begrotingen van de instellingen, organen en instanties van de Unie (kortweg EU-middelen). ${ }^{23}$ Onder strafbare feiten wordt, beknopt weergegeven, verstaan fraude in de vorm van het verkrijgen of achterhouden van EU-middelen door het verstrekken van onjuiste of onvolledige informatie of het achterhouden van informatie of het aanwenden van EUmiddelen voor andere doelen dan waarvoor zij oorspronkelijk zijn toegekend. Dit is nader gespecifieerd voor aanbestedingen en btw-fraude. ${ }^{24}$ In de praktijk gaat het veelal om fraude met middelen uit EU-structuurfondsen of andere subsidies, btw-fraude en douanefraude. ${ }^{25}$ Het bestrijden van fraude met middelen uit EUstructuurfondsen of andere subsidies noemen wij hierna de hoofdcompetentie van het EOM.

Daarnaast heeft het EOM een accessoire bevoegdheid ten aanzien van strafbare feiten die onlosmakelijk verbonden zijn met de hiervoor genoemde strafbare feiten. ${ }^{26}$ Een voorbeeld daarvan is valsheid in geschrift in het kader van het (ten onrechte) verkrijgen van een EUsubsidie. De EOM-verordening voorziet in een nadere 'subsidiariteitsafbakening' van deze bevoegdheden. De accessoire bevoegdheid geldt niet indien de maximumstraf voor het strafbare feit dat binnen de hoofdcompetentie valt, gelijk aan of lager is dan de maximumstraf voor het strafbare feit dat binnen de accessoire bevoegdheid valt. ${ }^{27}$ Het EOM is in het geheel niet bevoegd als de werkelijke of dreigende schade aan de financiële belangen van de Unie door een strafbaar feit waarvoor zij in beginsel bevoegd is, niet groter is dan de schade die een ander slachtoffer heeft geleden of dreigt te lijden. ${ }^{28}$ In dergelijke gevallen dient het EOM de zaak, na overleg, te verwijzen naar de bevoegde nationale vervolgingsautoriteit. Deze afbakening was niet voorzien in het voorstel en lijkt een tegemoetkoming te zijn aan subsidiariteitsbezwaren die zijn opgeworpen door nationale

21. Art. $6 \mathrm{EOM}$-verordening.

22. Art. $4 \mathrm{EOM}$-verordening.

23. Art. 2 lid 3 EOM-verordening.

24. Art. 3 EOM-verordening, voor btw-fraude geldt voorts op grond van art. 2 lid 2 een materialiteitsgrens van 10 miljoen euro.

25. Zie bijvoorbeeld Report from the Commission to the European Parliament and the Council: 29th Annual Report on the Protection of the European Union's financial interests - Fight against fraud - 2017, $\operatorname{COM}(2018) 533$ final, p. 14-16

26. Art. 22 lid 3 EOM-verordening. Zie in dit kader ook E. Sitbon, 'Ancillary Crimes and Ne Bis in Idem', in: Geelhoed, Erkelens en Meij 2018, p. $129-140$.

27. Art. 22 lid 3 sub a EOM-verordening.

28. Art. 22 lid 3 sub b EOM-verordening. parlementen. ${ }^{29}$ Met betrekking tot dit soort strafbare feiten kan het EOM strafrechtelijke onderzoeken instellen, strafvervolgingshandelingen verrichten en als openbaar aanklager optreden bij de bevoegde rechtbanken van de lidstaten totdat de zaak definitief is afgedaan (kortom, tot in hoogste resort). De bevoegdheid van het EOM is een gedeelde bevoegdheid van het EOM en de nationale autoriteiten, gebaseerd op het evocatierecht van het EOM. ${ }^{30}$ Dat evocatierecht betekent echter, zoals hierna nader zal worden besproken, dat het EOM leidend is.

\section{De inrichting van het $\mathrm{EOM}$}

Organisatorisch kent het EOM een centraal niveau en een decentraal niveau. ${ }^{31}$ Het centrale niveau bestaat uit onder meer de Europese hoofdaanklager, de Europese aanklagers, het college van Europese aanklagers (hierna: het College) en de permanente kamers. ${ }^{32}$ De Europese hoofdaanklager geeft leiding aan het EOM. Hij zit ook de vergaderingen van het College en de permanente kamers voor. ${ }^{33}$ Het EOM heeft daarnaast per lidstaat een Europese aanklager. Deze Europese aanklager houdt toezicht op onderzoeken en strafvervolgingen door de gedelegeerde Europese aanklagers in de lidstaat van die Europese aanklager. ${ }^{34}$ Het College bestaat uit de Europese hoofdaanklager en één Europese aanklager per lidstaat en is verantwoordelijk voor de algemene supervisie over het optreden van het EOM. Het beslist met name over strategische aangelegenheden. ${ }^{35}$ De permanente kamers bestaan uit de Europese hoofdaanklager (of een van diens plaatsvervangers) en overzien de meer operationele activiteiten van het EOM: zij monitoren de onderzoeken en strafvervolgingen die door de gedelegeerde Europese aanklagers worden gevoerd en geven daar leiding aan en zorgen voor de coördinatie van grensoverschrijdende onderzoeken. ${ }^{36}$

Het decentrale niveau bestaat uit de gedelegeerde Europese aanklagers die werkzaam zijn in de lidstaten. ${ }^{37} \mathrm{De}$ gedelegeerde Europese aanklagers treden namens het $\mathrm{EOM}$ in hun respectieve lidstaten op en hebben dezelfde bevoegdheden als nationale aanklagers. ${ }^{38}$ Elke lidstaat heeft twee of meer gedelegeerde Europese aanklagers die ook als nationaal aanklager kunnen optreden, mits dit hen niet belet te voldoen aan hun verplichtingen onder de EOM-verordening. ${ }^{39}$ Op voorstel van de Europese hoofdaanklager benoemt het College de gede-

29. Zie bijvoorbeeld Position Paper Tweede Kamer inzake oprichting van een Europees Openbaar Ministerie (EOM), Den Haag, 11 april 2014 en Kamerstukken I/ 2012/13, 22112, 1681, p. 6-7.

30. Overweging $13 \mathrm{EOM}$-verordening.

31. Art. 8 lid 2 EOM-verordening.

32. Art. 8 lid 3 EOM-verordening.

33. Art. 11 lid $1 \mathrm{EOM}$-verordening.

34. Art. 12 lid 1 EOM-verordening.

35. Art. 9 lid 1 en 2 EOM-verordening.

36. Art. 10 lid 1 en 2 EOM-verordening.

37. Art. 8 lid 4 EOM-verordening.

38. Art. 13 lid 1 EOM-verordening.

39. Art. $13 \mathrm{EOM}$-verordening. 
legeerd Europese aanklagers die door de lidstaten zijn voorgedragen. ${ }^{40}$ De gedelegeerde Europese aanklagers moeten vanaf hun benoeming tot hun ontslag actief lid zijn van de vervolgingsautoriteit of van de rechterlijke macht van de lidstaat die hen heeft voorgedragen. ${ }^{41}$ Het ligt daarmee voor de hand dat lidstaten één of meer van hun nationale officieren van justitie de (bij)rol van gedelegeerd Europees aanklager zullen geven. Het zijn dus deze gedelegeerde Europese aanklagers die het daadwerkelijke strafrechtelijke vervolgingswerk doen, als lid van de nationale vervolgingsautoriteit maar aangestuurd vanuit het centrale niveau van het EOM. In Nederland zullen ten minste twee officieren van justitie van het Openbaar Ministerie worden aangesteld als gedelegeerde Europese aanklagers. ${ }^{42}$

Een doel bij de inrichting van het EOM was om de gedelegeerde aanklagers onafhankelijk van hun lidstaat te laten functioneren. Artikel 6 lid 1 EOM-verordening bepaalt dan ook dat de lidstaten de onafhankelijkheid van het EOM respecteren en niet trachten het EOM te beïvloeden bij het vervullen van zijn taken. De gedelegeerde Europese aanklagers zijn aangesteld als officier van justitie door het Nederlandse Openbaar Ministerie en krijgen vervolgens de taak van gedelegeerde Europese aanklagers toebedeeld. Zij blijven werknemer van het Nederlandse Openbaar Ministerie, maar kunnen alleen worden ontslagen met instemming van het EOM. ${ }^{43}$ Het salaris van gedelegeerde Europese aanklagers wordt betaald door het EOM. ${ }^{44}$ Vreemd is dat de EOM-verordening toestaat dat gedelegeerde Europese aanklagers als nationaal aanklager blijven optreden mits dit hen niet belet te voldoen aan de verplichtingen die op hen rusten krachtens de EOM-verordening. ${ }^{45}$ Door twee verschillende banen te combineren, is het waarschijnlijk dat loyaliteitsproblemen ontstaan. Het is lastig zich voor te stellen dat een EOM-officier een grote strafzaak zou overdragen omdat hij in een andere strafzaak als gedelegeerd Europees aanklager moet optreden. Mochten nationale vervolgingsautoriteiten toestaan dat gedelegeerde Europese aanklagers ook als nationaal aanklager optreden, dan verdient het aanbeveling om hier duidelijke afspraken over te maken; zowel met de officier in kwestie als met het EOM.

\section{Onderzoek door het EOM}

De bevoegdheid van het EOM gaat boven de bevoegdheid van de nationale vervolgingsautoriteiten: als het EOM besluit zijn bevoegdheid uit te oefenen, oefenen de nationale vervolgingsautoriteiten hun bevoegdheid met betrekking tot diezelfde strafbare gedraging niet uit.

40. Art. 17 lid 1 EOM-verordening

41. Art. 17 lid 2 EOM-verordening

42. Art. 13 lid 2 EOM-verordening.

43. Art. 17 lid 4 EOM-verordening.

4. Art. 91 lid 4 EOM-verordening

45. Art. 13 lid 3 EOM-verordening.
Dat besluit om bevoegdheid uit te oefenen komt tot stand doordat het EOM een onderzoek opent of doordat het zijn 'evocatierecht' uitoefent. ${ }^{46} \mathrm{Om}$ het EOM daartoe in de gelegenheid te stellen, zijn de bevoegde instellingen, organen en instanties van de Unie en de bevoegde nationale autoriteiten verplicht het EOM in kennis te stellen van strafbare gedragingen ten aanzien waarvan het EOM zijn bevoegdheid zou kunnen uitoefenen. Daartoe bevat de EOM-verordening een meldplicht ten aanzien van zaken die vallen binnen de bevoegdheid van het EOM. ${ }^{47}$ Deze meldplicht dient zo ruim mogelijk te worden geinterpreteerd. ${ }^{48}$ Binnen vijf dagen na het ontvangen van de relevante informatie moet het EOM beslissen of het zijn evocatierecht inroept. ${ }^{49}$ Indien het EOM dat recht uitoefent, draagt de lidstaat het dossier over aan het EOM. ${ }^{50}$ Het EOM neemt de zaak dan volledig over; een gang van zaken die Folkert Jensma doet denken aan Amerikaanse politieseries waarin de FBI plots de zaak overneemt van de lokale sheriff. ${ }^{51}$

De gedelegeerde Europese aanklager doet onderzoek conform het nationale recht van de lidstaat waar hij officier van justitie is, of kan opdracht geven aan bevoegde autoriteiten in zijn lidstaat om onderzoek uit te voeren. ${ }^{52}$ Hij moet daarbij nauw samenwerken met andere gedelegeerde Europese aanklagers indien het een grensoverschrijdende zaak betreft. ${ }^{53}$ De deelnemende lidstaten moeten ervoor zorgen dat het EOM, voor onderzoek naar strafbare feiten waar minimaal vier jaar gevangenisstraf op staat, beschikking heeft over bepaalde onderzoeksbevoegdheden, zoals de doorzoekingen van gebouwen, het vorderen van gegevens en de onderschepping van elektronische communicatie. ${ }^{54}$ Mocht tijdens het onderzoek blijken dat het feitenkader van de zaak niet past binnen de hoofdcompetentie van het EOM, dan verwijst het EOM de zaak naar de bevoegde nationale autoriteiten. ${ }^{55}$

Als de behandelende gedelegeerde Europese aanklager zijn onderzoek voltooid acht, stuurt hij een samenvatting van de zaak en een conceptvervolgingsbeslissing naar de toezichthoudende Europese aanklager. Deze toezichthoudende Europese aanklager geeft dit door aan de permanente kamer die zich met de zaak bezighoudt. ${ }^{56}$ Die permanente kamer neemt daarna een vervolgingsbeslissing. ${ }^{57}$ De vervolgingsbeslissing van de permanente kamer kan ook inhouden dat wordt getracht een schikking met de verdachte te treffen. ${ }^{58}$ Alleen de permanente kamer kan besluiten om de zaak te seponeren

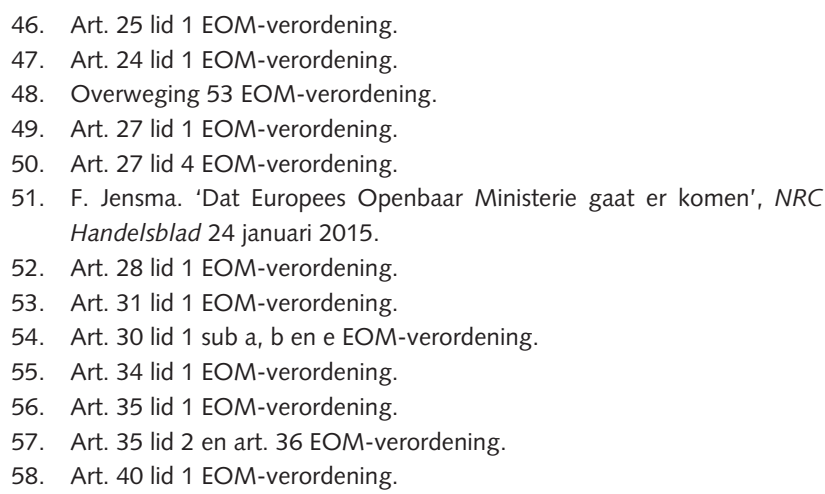


op basis van een limitatieve lijst met gronden, bijvoorbeeld omdat onvoldoende bewijs bestaat ${ }^{59}$ of omdat strafvervolging zou leiden tot strijd met het beginsel van ne bis in idem. ${ }^{60}$

Het is overigens onzeker of een sepot door het EOM een daaropvolgende vervolging door het Openbaar Ministerie wegens strijd met het beginsel van ne bis in idem belet. Artikel 50 Handvest bepaalt dat niemand opnieuw berecht of gestraft mag worden voor een strafbaar feit waarvoor hij in de Unie reeds onherroepelijk is vrijgesproken of veroordeeld. Deze bepaling ziet dus enkel op strafrechtelijke procedures die uitlopen in een vrijspraak of veroordeling; het sepot wordt in deze bepaling niet genoemd. Het Hof van Justitie bepaalde in het kader van de uitleg van artikel 54 Schengenuitvoeringsovereenkomst dat ook een sepot uit een andere lidstaat kan kwalificeren als onherroepelijke berechting. ${ }^{61}$ Het is echter niet toegelicht of dit ook geldt voor een sepot van het EOM. Oftewel, als het EOM een zaak tegen een persoon seponeert, is niet uitgesloten dat het Openbaar Ministerie deze zaak later oppakt. Een dergelijke gang van zaken kan in bepaalde gevallen strijd opleveren met beginselen van goede procesorde, waaronder met name het vertrouwensbeginsel. Het is dan ook zorgwekkend dat het EOM uitdrukkelijk de bevoegdheid krijgt om relevante informatie aan OLAF te geven indien het een zaak seponeert. ${ }^{62}$ Het verdient aanbeveling om op dit punt een en ander vanuit overheidswege te verduidelijken.

In Nederland zal de gedelegeerde officier van justitie in een EOM-zaak een voorstel doen voor een vervolgingsbeslissing. De vervolgingsbeslissing wordt vervolgens op Europees niveau genomen, namelijk door de permanente kamer onder toezicht van de Europese aanklager. Het Nederlandse Openbaar Ministerie verliest in zoverre dan ook zijn alleenheerschappij voor wat betreft het opportuniteitsbeginsel. De deelname van Nederland aan het EOM is daarmee in strijd met het regeerakkoord van het kabinet-Rutte III. In het regeerakkoord stond namelijk dat 'toetreding zal plaatsvinden onder de voorwaarde dat dit geen afbreuk doet aan het opportuniteitsbeginsel van het Nederlandse Openbaar Ministerie'. ${ }^{63}$

Ook voor slachtoffers kent de EOM-procedure verschillen ten aanzien van een reguliere Nederlandse strafrechtelijke procedure. Indien een slachtoffer het oneens is met een beslissing van het Openbaar Ministerie, staat naar Nederlands recht de procedure van artikel 12 Wet-

59. Art. 39 lid 1 sub g EOM-verordening

60. Art. 39 lid 1 sub f EOM-verordening.

61. HvJ 5 juni 2014, zaak C-398/12, Procura della Repubblica/M, ECLI:EU:C:2014:1057

62. Art. $101 \mathrm{EOM}$-verordening.

63. 'Vertrouwen in de toekomst, Regeerakkoord 2017-2021 VVD, CDA, D66 en ChristenUnie', www.rijksoverheid.nl/binaries/rijksoverheid/ documenten/publicaties/2017/10/10/regeerakkoord-2017-vertrouwen -in-de-toekomst/Regeerakkoord+\%27Vertrouwen+in+de+toekomst \%27.pdf, 10 oktober 2017. Een eerdere fout in het regeerakkoord ten aanzien van het EOM is in deze versie verbeterd. Zie in het kader van het opportuniteitsbeginsel en het EOM ook W. Geelhoed, 'Het Europees Openbaar Ministerie en het opportuniteitsbeginsel in Nederland', Strafblad 2018/6. boek van Strafvordering (Sv) voor hem open. Door middel van die procedure kan hij proberen strafrechtelijke vervolging af te dwingen. De EOM-evenknie van deze bepaling is artikel 42 lid 3 EOM-verordening. Slachtoffers moeten dan echter beroep instellen bij de Unierechter overeenkomstig artikel 263 lid 4 VWEU. De Unie noch de Nederlandse overheid heeft duidelijkheid verschaft of de artikel $12 \mathrm{~Sv}$-procedure openstaat voor een Nederlands slachtoffer bij een sepot door het EOM. De wettekst van artikel $12 \mathrm{~Sv}$ wijst er echter op dat deze procedure niet openstaat.

\section{De toekomst van het EOM en OLAF}

Het is te vroeg om te voorspellen welke veranderingen de komst van het EOM gaat brengen voor OLAF. De vacature voor de Europese hoofdaanklager is nog niet lang geleden geplaatst ${ }^{64}$ en het EOM zal op z'n vroegst eind 2020 aan de slag gaan. Het is echter geen geheim dat de Commissie nu al haar zinnen heeft gezet op een uitbreiding van het takenpakket van het EOM. In 2017 heeft de voorzitter van de Commissie, Jean-Claude Juncker, al geopperd de taken van het EOM uit te breiden naar terrorismebestrijding. ${ }^{65}$ De Commissie heeft in 2018 dat idee geconcretiseerd in een mededeling. ${ }^{66}$ De voornaamste reden die de Commissie noemt voor een dergelijke uitbreiding van de bevoegdheid van het EOM is dat de huidige samenwerking ter bestrijding van grensoverschrijdend terrorisme tekortschiet, met name op de punten van informatie-uitwisseling en coördinatie van onderzoeks- en vervolgingshandelingen. Daardoor zouden gaten dreigen te ontstaan in de aanpak van grensoverschrijdende terrorismenetwerken. ${ }^{67}$ Hoewel Eurojust en Europol een belangrijke coördinerende rol kunnen spelen, kunnen zij dat alleen op verzoek van de nationale autoriteiten, die een dergelijk verzoek niet altijd doen. ${ }^{68}$

De mogelijkheid van een dergelijke uitbreiding is voorzien in artikel 86 lid 4 VWEU. Op grond van deze bepaling kan de Raad de bevoegdheden van het EOM bij de bestrijding van ernstige criminaliteit met een grensover-

64. Europees Openbaar Ministerie (EOM), Bekendmaking van een vacature voor de functie van Europees hoofdaanklager - Luxemburg Tijdelijke functionaris AD 15, PbEU 2018, C 418/A1.

65. Voorzitter Jean-Claude Juncker, Toespraak over de Staat van de Unie 2017, http://europa.eu/rapid/press-release_SPEECH-17-3165_nl.htm, 13 september 2017

66. Communication from the Commission to the European Parliament and the European Council, A Europe that protects: an initiative to extend the competences of the European Public Prosecutor's Office to crossborder terrorist crimes, $\operatorname{COM}(2018) 641$ final. Zie in dit kader ook M.F.H. Hirsch Ballin, 'Uitbreiding van het EOM-mandaat: een positieve verplichting tot samenwerking bij terrorismebestrijding', Strafblad 2018/6.

67. Communication from the Commission to the European Parliament and the European Council, A Europe that protects: an initiative to extend the competences of the European Public Prosecutor's Office to crossborder terrorist crimes, $\operatorname{COM}(2018) 641$ final, p. 4-8

68. Idem, p. 5 
schrijdende dimensie uitbreiden. De redenen voor de door de Commissie voorgestelde uitbreiding zijn, ons inziens, echter minder sterk dan de redenen waarvoor het EOM oorspronkelijk is opgericht. De oprichting van het EOM was niet alleen ingegeven door het belang van het verbeteren van grensoverschrijdende samenwerking, maar ook als oplossing voor de inactiviteit van de lidstaten bij het bestrijden van strafbare feiten die de financiële belangen van de Unie schaden. Niet is gebleken (of gesteld door de Commissie), dat bij de aanpak van grensoverschrijdend terrorisme ook sprake zou zijn van een inactiviteit van de lidstaten die het beste door een supranationale organisatie als het EOM doorbroken kan worden. De lidstaten hebben bij de bestrijding van (grensoverschrijdend) terrorisme ten slotte een duidelijker direct eigen belang dan bij de bestrijding van fraude met EU-middelen. De redenen die de Commissie noemt voor de uitbreiding van de bevoegdheden van het EOM tot grensoverschrijdend terrorisme zouden bovendien net zo goed op kunnen gaan voor andere vormen van grensoverschrijdende criminaliteit. Uitbreiding zou dus een precedent zijn voor een steeds verdere uitbreiding van de bevoegdheden van het EOM. Zo heeft de directeur-generaal van OLAF al in een vroeg stadium geopperd dat de taken van het EOM ook uitgebreid zouden kunnen worden naar mensenhandel en grensoverschrijdende misdaad ${ }^{69}$ Corstens zei over verdere uitbreiding van het takenpakket van het EOM: 'Het gevaar bestaat hier dat de Europese Raad onder politieke druk de rol van het EOM gaat uitbreiden zonder dat er een goed doordachte visie over de onderscheiden rollen van nationale en EU-strafrechtsplegingen aan ten grondslag ligt. ${ }^{70}$ Een dergelijke uitbreiding zal, net als de oprichting van het EOM, niet zonder slag of stoot gaan. De Nederlandse regering heeft al het standpunt ingenomen dat een uitbreiding van de bevoegdheden van het EOM niet aan de orde is. In de eerste plaats omdat het EOM eerst goed moet worden opgericht en geëvalueerd en in de tweede plaats omdat de operationele noodzaak voor een dergelijke uitbreiding ontbreekt. ${ }^{71}$

De komst van het EOM zal ook consequenties hebben voor OLAF. Waar eerst OLAF de drijvende kracht was achter onderzoek naar fraudegevallen waardoor de financiële belangen van de EU worden geschaad en het aanzwengelen van strafrechtelijk optreden op nationaal niveau, worden deze taken nu grotendeels gecentraliseerd in het EOM. Het EOM kan echter niet alle taken van OLAF overnemen; al is het maar omdat niet alle lidstaten meedoen met het EOM en OLAF ook bevoegd is ten aanzien van onregelmatigheden die geen strafbare feiten behelzen.

De toekomstvisie van de Commissie voor OLAF blijkt onder meer uit het voorstel ${ }^{72}$ dat zij heeft gedaan tot

69. EU Observer, EU prosecutor likely to expand powers, https:// euobserver.com/justice/12228528, 28 november 2013

70. G.J.M. Corstens, 'De strafrechtspleging na Lissabon', Trema 2010, nr. 9, p. 385.

71. Kamerstukken II 2017/18, 33709, 14, p. 4.

72. Voorstel voor een verordening van het Europees Parlement en de Raad tot wijziging van Verordening (EU, Euratom) nr. 883/2013 betreffende wijziging van Verordening (EU) nr. 883/2013, ${ }^{73}$ de basisverordening voor OLAF. Het voorstel voorziet in bepalingen die de toekomstige samenwerking tussen $\mathrm{OLAF}$ en het EOM regelen en bepalingen die enkele tekortkomingen in het huidige onderzoeksinstrumentarium van OLAF moeten ondervangen. Ook in de EOMverordening wordt de voorgenomen 'nauwe samenwerking' tussen het EOM en OLAF beschreven. ${ }^{74}$ Wat opvalt, is dat het EOM een rol boven OLAF lijkt te krijgen. Als het EOM een onderzoek verricht, zal OLAF geen parallel administratief onderzoek instellen. ${ }^{75}$ Andersom geldt deze una via-bepaling niet voor het EOM: het mag een onderzoek starten als OLAF al een administratief onderzoek uitvoert. Daarnaast kan het EOM steun vragen aan OLAF, bijvoorbeeld om informatie te verstrekken, acties te coördineren of administratief onderzoek te verrichten. ${ }^{76}$ Ook krijgt het EOM toegang tot informatie in het casemanagementsysteem van OLAF op basis van een hit/no hit-systeem. ${ }^{77}$

\section{Rechtsbescherming bij vervolging door EOM}

$\mathrm{Bij}$ een eerste lezing van de regels rondom het EOM lijkt de verdachte voldoende rechtsbescherming te genieten, omdat de strafvorderlijke regels gelden van de lidstaat waar het onderzoek wordt uitgevoerd. Bovendien behoren grondrechten tot de algemene beginselen van het Unierecht en is het EOM gebonden aan het Handvest van de grondrechten van de EU. ${ }^{78}$ Aangezien het nationale strafprocesrecht geldt voor strafprocessen door een EOM-officier, zal een rechtssubject over het algemeen weinig verschil merken tussen vervolging door een Nederlandse officier van justitie en een EOM-officier. Met betrekking tot de onderzoeksfase kunnen zich echter problematische gevallen voordoen voor wat betreft rechtsbescherming.

Doordat de strafvorderlijke regels gelden van de lidstaat waar het onderzoek wordt uitgevoerd, kan het EOM

onderzoeken door het Europees Bureau voor Fraudebestrijding (OLAF) wat betreft samenwerking met het Europees Openbaar Ministerie en de doeltreffendheid van onderzoeken van OLAF, COM(2018) 338 final.

73. Verordening (EU, EURATOM) nr. 883/2013 van het Europees Parlement en de Raad van 11 september 2013 betreffende onderzoeken door het Europees Bureau voor Fraudebestrijding (OLAF) en tot intrekking van Verordening (EG) nr. 1073/1999 van het Europees Parlement en de Raad en Verordening (Euratom) nr. 1074/1999 van de Raad.

74. Overweging 103 EOM-verordening kan worden gezien als uitgangspunt.

75. Art. 101 lid 2 EOM-verordening.

76. Art. 101 lid 3 EOM-verordening.

77. Art. 101 lid 5 EOM-verordening.

78. Voor een achtergrond en voorbeelden van de werking van fundamentele rechten bij Europees strafrechtelijk optreden, zie J.F.H. Inghelram, 'Fundamental Rights, the European Anti-Fraud Office (OLAF) and a European Public Prosecutor's Office (EPPO): Some Selected Issues', Critical Quarterly for Legislation and Law 2012, 95, 1, p. 67-81. Voor een achtergrond ten aanzien van de rol van het Handvest bij gedragingen van het EOM, zie V. Mitsilegas en F. Giuffrida, 'The European Public Prosecutor's Office and Human Rights', in: Geelhoed, Erkelens en Meij 2018, p. 61-66 
forumshoppen. ${ }^{79}$ Het EOM kan immers in bepaalde gevallen kiezen in welke lidstaat opsporingsmiddelen het gemakkelijkst kunnen worden ingezet. Voor het afluisteren van telefoongesprekken tussen een persoon in Nederland en een persoon in Italië, kan het EOM bijvoorbeeld kiezen welk van de twee rechtssystemen het gemakkelijkst kan worden gebruikt voor de telefoontap. De minister van Justitie en Veiligheid merkt in dit kader op: 'Forumshopping door het EOM is als risico genoemd, maar in werkelijkheid bepalen de feiten en omstandigheden uiteindelijk de vervolging. ${ }^{80}$

Daarnaast is het voor een rechter moeilijk te beoordelen of het EOM de regels voor de inzet van opsporingsmiddelen heeft gevolgd die in een andere lidstaat gelden. In Nederland moet een rechter bij een beroep op artikel 359a Sv dan immers niet alleen zijn eigen recht, maar ook het recht van de lidstaat waar het opsporingsmiddel is ingezet, toetsen. Dit probleem bestaat nu ook al bij vervolging waarbij gebruik wordt gemaakt van bewijs dat in een andere lidstaat is verkregen. Door het grensoverschrijdende karakter van EOM-zaken zal dit probleem vaker voorkomen bij vervolging door een EOMofficier. De EOM-verordening biedt echter geen oplossing voor dit probleem. De minister van Justitie en Veiligheid reageerde als volgt op de vraag of een Italiaanse rechter gaat toetsen of een huiszoeking in Berlijn goed heeft plaatsgevonden:

'De zittingsrechter beoordeelt het gehele dossier. In het voorbeeld (...) zou de Italiaanse rechter het gehele dossier beoordelen. Hij moet daarbij afgaan op de gedelegeerde officier van justitie. Dat is ook degene die het bewijs moet overleggen [sic] dat als er in Duitsland opsporing heeft plaatsgevonden, er is gehandeld conform de Duitse opsporingsregelen. De zittingsrechter heeft de bevoegdheid om de lokale Duitse rechter alsnog te vragen om uitleg naar Duits recht. ${ }^{81}$

De minister geeft echter niet aan wat de wettelijke grondslag voor een dergelijk uitlegverzoek is; mogelijk doelt hij op het Aanvullend Protocol bij de Europese Overeenkomst nopens het verstrekken van inlichtingen over buitenlands recht. Wij zijn echter niet bekend met jurisprudentie waaruit blijkt dat dit protocol daadwerkelijk wordt gebruikt. Het verdient dan ook aanbeveling om naar dit protocol te verwijzen in de EOM-verordening, of een ander systeem aan te leggen voor de beoordeling door rechters van het recht van buitenlandse lidstaten.

Tot slot is problematisch dat de toetsing van de inzet van opsporingsmiddelen niet in alle lidstaten op hetzelfde moment in de strafrechtelijke procedure plaatsvindt. Wanneer twee rechtssystemen worden gecombineerd,

79. Voor een uiteenzetting van het risico van forumshopping, zie V. Mitsilegas en F. Giuffrida, 'Raising the bar? Thoughts on the establishment of the European Public Prosecutor's Office', CEPS Policy Insight 2017/39, p. 12-16.

80. Kamerstukken / 2017/18, 33709, 25, item 7.

81. Kamerstukken / 2017/18, 33709, 25, item 7. waarbij een systeem een zwaartepunt kent bij toetsing vooraf, terwijl andere systemen zich kenmerken door toetsing achteraf, kan het zijn dat uiteindelijk beperkte rechtsbescherming aan de verdachte toekomt. Het is onduidelijk wanneer wordt getoetst en wie toetst, als eerst een huiszoeking plaatsvindt in een lidstaat die toetst tijdens de inhoudelijke behandeling, terwijl de inhoudelijke behandeling plaatsvindt in een lidstaat die toetst voorafgaand aan de huiszoeking. Er is dan sprake van een zogenoemde systeembreuk, waarbij de verdachte tussen wal en schip valt. ${ }^{82}$ Vanuit rechtsstatelijk opzicht is dat zeer problematisch. Het Europees Parlement heeft in een resolutie opgenomen dat 'elk door het Europees Openbaar Ministerie genomen operationeel besluit dat gevolgen heeft voor derden vatbaar moet zijn voor rechterlijke toetsing door een bevoegde nationale rechter'. ${ }^{83}$ Het huidige wetsvoorstel verschaft daar geen duidelijke reactie op. Dit probleem had kunnen worden ondervangen door de Unierechter bevoegd te verklaren voor het toetsen van handelingen van het EOM in de prevervolgingsfase,${ }^{84}$ of door een procedure voor een legal opinion van een buitenlandse rechter in te stellen. Het eerstgenoemde is echter expliciet uitgesloten op basis van artikel 42 EOM-verordening. Het laatstgenoemde kent geen wettelijke grondslag. In de literatuur wordt al nagedacht over oplossingen voor het gat voor wat betreft rechterlijke controle van activiteiten van het EOM, waaronder de oprichting van specialised courts voor de toetsing van gedragingen van het EOM. ${ }^{85}$ De Unie zou er goed aan doen om voor een oplossing te zorgen, zodat er geen gaten voor wat betreft rechtsbescherming ontstaan.

\section{Conclusie}

$\mathrm{Na}$ een uitgebreide aanloop zal het EOM eind 2020 zijn werkzaamheden aanvangen. Gezien de aanzienlijke hoeveelheid fraude met EU-middelen is het goed dat op dit gebied een slag wordt geslagen. Voor het EOM is in beginsel een fraaie balans tussen Europese krachten en nationale wetgeving gevonden door het instellen van een aansturend Europees orgaan dat werkt met de regels van het nationale strafrecht. Door deze combinatie kan het EOM echter in bepaalde gevallen kiezen welk rechtssysteem het gebruikt. Aangezien het hier gaat om strafrechtelijke opsporing, kan het daarbij gaan om verregaande dwangmiddelen, zoals het betreden van wonin-

82. A.M.M. Orie, 'De verdachte tussen wal en schip óf de systeembreuk in de kleine rechtshulp', in: E. André de la Porte e.a. (red.), Bij deze stand van zaken, Arnhem: Gouda Quint 1983. Zie ook A. Hoek en M.J.J.P. Luchtman, 'Transnational Cooperation in Criminal Matters and the Safeguarding of Human Rights', Utrecht Law Review 2005, nr. 2, p. 1-39.

83. Resolutie van het Europees Parlement van 5 oktober 2016 over het Europees Openbaar Ministerie en Eurojust (2016/2750(RSP)).

84. V. Mitsilegas en F. Giuffrida, 'The European Public Prosecutor's Office and Human Rights', in: Geelhoed, Erkelens en Meij 2018, p. 78-87.

85. V. Mitsilegas en F. Giuffrida, 'The European Public Prosecutor's Office and Human Rights', in: Geelhoed, Erkelens en Meij 2018, p. 86. 
gen en het afluisteren van telefoongesprekken. Hier is dan ook sprake van een waakhond die bijten kan, en geen papieren tijger, voor de bestrijding van fraude met EU-middelen. Bovendien is het een waakhond die in de toekomst mogelijk zijn bevoegdheden zal zien uitbreiden. $\mathrm{Bij}$ een vervolgingsautoriteit als het EOM hoort dan ook adequate rechtsbescherming voor degenen die in het vizier van het EOM komen. In het kader van die rechtsbescherming valt voor de wetgever nog winst te behalen. Ook vanuit een subsidiariteitsperspectief is het EOM alles behalve een papieren tijger. Voor nu zijn de bevoegdheden van het EOM beperkt tot strafbare feiten die ten koste gaan van de EU-begroting. Het is echter duidelijk dat de ambities van de Commissie ten aanzien van de bevoegdheden van het EOM veel verder strekken. Indien de Commissie deze ambities handhaaft, valt te verwachten dat de subsidiariteitsdiscussie met de lidstaten over het EOM opnieuw - en ditmaal waarschijnlijk nog feller - zal oplaaien. Hoewel het EOM nu alleen op papier bestaat, laten deze ontwikkelingen zien dat zelfs een sluipende (vooralsnog) papieren tijger, vanuit een subsidiariteitsperspectief, niet ongevaarlijk is. 